\title{
Leadership Self-efficacy and Managerial Job Performance in Nigerian Commercial Banks
}

\author{
Shehu Inuwa Galoji”, Fais Ahmad, Husna Johari \\ Department of Business University Utara Malaysia \\ mogaloji@yahoo.com, fais@uum.edu.my,husna@uum.edu.my
}

\begin{abstract}
The objectives of this study is to examine the relashionship between leadership self efficacy and managerial job performance in the Nigerian commercial banks. Data was collected among the branch managers of the banks. A total of four hundred and thirteen responces were used for analysis. SPSS software for windows version 16 was used to conduct a factor analysis, reliability test and the correlations analysis. The result shows that leadership self efficacy is related to managerial job performance.
\end{abstract}

Keywords Leadership Self Efficacy, Managerial Job Performance, Banks, Nigeria

\section{Introduction}

Leaders in various organisations around the world today are facing numerous challenge as they regularly are struggling to adapt to the acceleratig changes in their organisations which is both internally and externally embedded in the environment (Avolio \& Luthans, 2006; Hooijberg, Hunt, \& Dodge, 1997; Lord \& Hall, 2005; Hannah, Avolio, Luthans \& Harns 2008) hence this situation not only challenges the leaders ability, their skills or knowledge but even questioning their capabilities of leading their organisation or the psychological resources needed in meeting the ever acellarated demnd of their managerial job roles. In the past, the banking sector in Nigeria has witnessed what had been seen as a dramatic growth at the post consolidation era but unfortunately the industry and the regulators are not sufficientlty ready or prepared to sustain and monitor the growth (Sanusi, 2010).

But before the consolidation of the banks i.e. prior to 2004, the Nigerian financial system is pointing to an inevitable collapse as a result of corruption, poor corporate governance with issues related to high turnover by the management and staff of the banks, insider abuse (Cowry research, 2009). The sector reported the liquidation of some banks earlier iin 1996 to which later the central bank consolidated or trim the number of banks to 25 . In the Nigerian banking sector today, the story is not different from other corporate scandals around the world as the Central Bank of Nigeria recently announce the removal of 5 of the leaders of some banks and replace them with a set of managerial team.

* Corresponding author:

mogaloji@yahoo.com(Shehu Inuwa Galoji)

Published online at http://journal.sapub.org/economics

Copyright (C) 2012 Scientific \& Academic Publishing. All Rights Reserved
The major challenges that these leaders face today have put question on their competency, ability and skills towards their managerial performance.

This call to the question of the managerial job performance by the leaders in those organisations as the problem is seen to be caused by in-ability of the leaders in the banks to carry out their responsibilities hence not concentrating on their managerial role performance. In linking this issue with the academic research, studies in the in the past had considered the idea of job performance factor as a single job performance factor (eg Campbell, McCloy, Oppler \& Sager, 1993) thus relying on this singular factor model have impeded progress in the understanding of the predictor criterion relations (Campbell et al. 1993; Conway, 1996). Rodney A. McCloy, John P. Campbell, and Robert Cudeck (1994) assumed that virtually all performance in any job is multidimentional. Semader et al (2006) conducted their study by using a single item measure to assess managerial performance therefore it does not address the multidimensionality of job performance. They suggested that accounting for the multidimensional aspects of managerial job performance is certainly an important avenue for future research direction. It was also observed by Paglis (2010) that the weaker result from the work of Semader et al (2006) could be best explained from the inconsistency between the scope of the LSE and performance measures as they used a single-item overall performance appraisal score to measure managerial performance (Paglis, 2010). Robertson \& Sadri (1993) also recommended future study to measure managerial efficacy on managerial performance. This study is aimed at closing this gap.

Traits such as self efficacy and high expectations are often included when theorist consider the issue of effective leadership which leads to higher performance (House \& Shamir, 1993; Chemer, 2001). Self efficacy can be said to be par- 
ticularly salient in a crisis situation as it is seen as person's overall estimate of his/her ability to achieve requisite performance in achievement situations (Schunk, 1983; Eden \& Zuk, 1995; Ross \& Gray, 2006). Leadership efficacy is regarded as one of the most important variable that determines the individual, the group and outcomes of the organisations activities as it also plays a very important role particularly under stress or demending situation (Hoyt, 2005). Leadership self-efficacy can be refered to as a person's perception of his/her general ability to lead (Murphy, 1992). Several researches conducted in the past have shown strong and positive association between self-efficacy and several forms of human performance (e.g. Holden, 1991; Multon et al., 1991; Stajkovic \& Luthans, 1998; Semadar et al, 2006; Anderson et al, 2008).

Considering the managerial issue and the reserch gap highlited, this study considers managerial job performance of Borman and Motowidlo (1993) task and contexual performance. Furthermore, leadership self efficacy is considered based on self discipline, serve, involve, project credibility and challenge LSE as suggested by Anderson et al (2008).

\section{Manajerial Job Performance}

McCloy, Campbell and Cudeck, (1994) defined the term performance as those behaviours or actions which are regarded relevant to those goals of the said organisation in question. They futher argued that performance itself cannot be said to be the outcome itself, consequences or the result of behaviors or action but rather performance can be said it is the action itself. Thus they argued that performance tends to be multidimensional, a situation whereby for any specifictype of job, there tends to be a number of substantive performance components that are distinguished interms of their intercorrelations and patterns on covariation with other variables. Campbell, McCloy, Oppler and Sager (1993) provided i.e. Job-specific task proficiency, non-job-specific task proficiency, written \& oral communication task proficiency, demonstrating effort, maintaining personal discipline, facilitating peer and team performance, suprvision/leadership, management/administration. Borman and Brush (1993) used factors analysis/expert judgement to provide 18 mega dimensions under a parsimonious group of four dimensions.

Mat (2008) observed based on cohession among group performance that it is very important to differentiate ask from interpersonal performance as it provides inportant practical implications within the organization. The managerial job performance of the leaders in the organization will hence be more defined if the task and contextual performance of the leaders is ascertained in this study as task performance is more of the technical core and the contextual performance is more of interpersonal relations in the organizations. Furthermore, it will enable the managers in the organizations to know about their roles.

\section{Leadership Self Efficacy}

According to Paglis (2010), due to the lack of agreement or concensous in the literature on the definition of leadership and how it looks like, it had made researchers to diverge in their approaches to studying LSE. She further argued that this had make it much more difficult in approaching LSE hence its definition as most of the researchers gave it a broad definition i.e. Kane (1999) defined LSE as "one's perceived self-capability to perform cognitive and behavioral functions required to effectively perform a specific leadership task". Hoyt (2005), sees leadership efficacy as an important domain which determines the organisational outcomes, individual and groups as it plays particular roles in especially stressful conditions. Murphy (1992) also sees leadership self-efficacy as one's perception regarding his or her general capabilities to lead. Bandura (1997) argued that self efficacy in general is quite domain specific, thus self-efficacy for leadership not generalized self-esteem, positive affect, or locus of control should relate to leadership effectiveness (Hoyt, 2005).

\section{Methodology}

This study was a correlation study type of survey design. This type of study is considered suitable for collecting primary data. Correlation studies are conducted in other to identify important factors that are associated with the problems thus the choice of this method solely depends on those research questions asked and how the said problem is defined (Sekaran \& Baugie, 2009). As this study is aimed at examining leadership self-efficacy and managerial job performance, this study was conducted based on primary data collected via the use of survey design.

This study was conducted by the use questionnaire form of data collection. In this form, a face to face method of questionnaire distribution was adopted and a total number of 1000 questionnaires were sent out to the respondents. The units of analysis of this study are the individual branch managers of the sample chosen from all the branches of the Nigerian commercial banks under study. Before the questionnaires were sent out, it was sent for expert face validity and suggestions. The questionnaire consist of 24 item measures the measure leadership self efficacy. This was adapted from the work of Anderson et al (2008). The managerial job performance was measured by 13 item measures adapted from Borman and Motowidlo (1993). A 5 point Likert style was used with options that ranges from (1) unable; (2); "low" (3); "moderate" (4); "high" (5); "certain". Thereafter, the reliability test was conducted. Among the questionaires that were returned, 457 were considered suitable for analysis. After checking for outliers, a factor analysis and reliability test was conducted. Subsequently, the correlation test was also conducted.

The underpinning theory of this study is self-efficacy theory. According to Bandura \& Wood (1989), perceived 
self efficacy operates as as central factor that acts in the self-regulatory mechanisms which governs human motivation and actions. The stronger a person's perceived self-efficacy to achieve a certain level of performance, the higher the persons set goals for themselves and thus they become firm to such commitment on such goals.

\section{Results}

\subsection{Factor Analysis and Reliability of Measures}

In conducting the analysis of this study, SPSS software for windows version 16 was used in analyzing the data collected. First is the check for missing values to which the result shows none has missing value. The next is the check for outliers to which 44 cases were found to be outliers among the 457 results and were deleted. Subsequently, a factor analysis was conducted based on the variables under study. Leadership self efficacy was factor analyzed based on the 24 items that measure the variable. The test resulted in the deletion of 4 items thus 20 items measured leadership self efficacy based on the dimensions of self discipline LSE (3), involve LSE (4), serve LSE (4), perceived credibility LSE (5) and challenge LSE (4). The correlation matrices, anti image, $\mathrm{KMO}$, commonalties, cumulative and the rotated matrix were ascertained be good (see table2). Furthermore, the reliability test of the dimensions were conducted and the result shows self discipline (.76), involve (.73), serve (.78), perceived credibility (.81) and challenge (.78) LSE and the overall leadership self efficacy shows a reliability of (.64) (refer to table 1).

Secondly, the factor analysis on managerial job performance was conducted. Here also the correlation matrices, anti image, KMO, commonalties, cumulative and the rotated matrix were studied carefully as the test resulted to the deletion of 3 items from the 13 items to measure managerial job performance. Therefore, the dimensions were measured by contextual performance (5) and task performance (5) questions respectively. The number of Items, $\mathrm{KMO}$ and Bartlett's Test and Cumulative are summarised in (see table 2). Subsequently also, reliability test was conducted and the result shows contextual performance (.83) and task performance (.88) to which the overall cronbach alpha value of managerial job performance is .79 (see table 1).

\subsection{Correlation Analysis Result}

A person correlation was conducted to ascertain the level of correlation between the dimensions of the independent variable (LSE) and managerial job performance. Correlation analysis or test measures the level of significance between two variables in other to see their level of relationship (Hair, Samouel, Money and Page, 2007. They further suggested the degree or strength of the relationship based on rule of thumb to be i. e. $0.91-1.00$ very strong, $0.71-0.90$ high, $0.41-0.70$ moderate, 0.21-0.40 small but definite relationship, 0.00-0.20 slight, almost negligible. The correlation result of the study shows that the correlation between the five dimensions of LSE i.e. self discipline, involve, serve, perceived credibility and challenge (.78) LSE, only self discipline LSE has a positive correlation with contextual performance on .582 which is moderate. In the other hand, only perceived credibility LSE has a positive correlation with task performance on .377 which is small but definite relationship hence this are the only significant result among the correlation based on the dimensions. The second idea was the correlation between the construct of the independent variable (leadership self efficacy) and the dependent variable (managerial job performance). The result shows that there was significant relationship between the independent variable and the dependent variable. it shows that the strength of the correlation stood at .314 an this shows small but definite relationship.

\section{Discussion}

As the objective of this study is to examine the relationship between leadership self efficacy and managerial job performance, the gap that exist on the need for this study had been in common with the managerial issues in so many organization around the world as leaders are ever challenged with their performance or job demands. The idea of measuring the multi dimensionality of job performance as recommended by Semadar et al (2006) and the need for future studies to be conducted on leadership self efficacy by Anderson et al (2008), it can be said the result of this study has met the objectives of this study. This study measures the multi dimensionality of managerial job performance and leadership self efficacy and the relationship was found to be significant. This is in concord with past studies (Semadar et al, 2006; Stajkovic and Luthans, 1998; and Robertson and Sadri, 1993). Based on the managerial issue discussed, this study, the Nigerian banking sector, its regulators, policy makers and the government will benefit from this study. As can be seen recently, the situation un earthed in the banking industry calls for outmost concern and urgency in such studies in other to ascertain the type of leaders needed in the system especially in the banks that record low performance in the current situation. This study has added to the body of knowledeg and literature on the criterion issue of managerial performance construct as it measures manajerial job performance on its relationship to leadership self efficacy as past study on this study by Semadar et al (2006), Stajkovivc and Luthans (1998) did not consider the multidimentionality of managerial job performance. Hence this study will add to the body of knowledghe by considering the task and contexual performance dimentions of Borman and Motowidlo (1993) as suggested by Semadar et al (2006).

\section{Conclusions}

This study has shown the gap that exists in the literature 
and tried in covering them. The factor analysis and the reliability test were conducted and the result all shows to be in good shape and further analysis was conducted to see the strength of the relationship between the independent variable and the dependent variable. The result shows the constructs are significantly related. Most of the dimensions did not have a significant relationship. The overall correlations though are in concord with past study thereby supporting the result.

\section{REFERENCES}

[1] A. Bandura and R. Wood (1989). Effect of perceived controllability and performance standards on self-regulation of complex decision making. Journal of Personality and Social Psychology, 56, 805-814.

[2] A.D. Stajkovic, and F. Luthans (1998). "Self-efficacy and work-related performance: a meta-analysis". Psychological Bulletin, Vol. 124, pp. 240-61.

[3] A. Jenkins (1994). The role of managerial self-efficacy in corporate compliance with the law. Law and Human Behavior, $18,71-88$.

[4] A. Semadar, G. Robins, and G. Ferris (2006). Comparing the validity of multiple social effectiveness constructs in the prediction of managerial job performance. Journal of Organizational Behavior, 27, 443-461.

[5] D. W. Anderson, H. T. Krajewski, R. D. Goffin, and D. N. Jackson, (2008). A leadership self-efficacy taxonomy and its relation to effective leadership. The Leadership Quarterly 19 595-608.

[6] F. H. Joseph, Jr., C. B. William, J. B. Barry and E. A. Rolph, Multivariate Data Analysis Pearson Prentice Hall

[7] F. L. Schmidt, J. E. Hunter and A. N. Outerbridge (1986) Impact of job experience and ability on job knowledge, work sample performance, and supervisory ratings of job performance. Journal of Applied Psychology, 71, 432-439.

[8] F. Luthans and S. J. Peterson, (2002). Employee engagement and manager self-efficacy: Implications for managerial effectiveness and development. Journal of Management Development, 21(5), 376-387.

[9] I. T. Robertson, and G. Sadri. (1993). Managerial self-efficacy and managerial performance. British Journal of Management, 4, 37-45.

[10] L. L. Paglis and S. G. Green (2002). Leadership self-efficacy and managers' motivation for leading change. Journal of Organizational Behavior, 23, 215-235.

[11] L.S. Sanusi (2010). "The Nigerian Banking Industry: what went wrong and the way forward" Being the full text of a Convocation Lecture delivered at the Convocation Square, Bayero University, Kano, on Friday 26 February, 2010 to mark the Annual Convocation Ceremony of the University Central Bank of Nigeria Governor's Speech.

[12] M. J. McCormick (2001). Self-efficacy and leadership effectiveness: Applying social cognitive theory to leadership. Journal of Leadership Studies, 8, 22-33.

[13] M. J. McCormick, J. Tanguma and A. S. Lopex-Forment (2002). Extending self-efficacy theory to leadership: A review and empirical test. Journal of Leadership Education, 1, 34-49.

[14] M. J. Ree, J. A. Earles, and M. S. Teachout (1994) Predicting Job Performance: Not Much More Than $g$ Journal of Applied Psychology . Vol. 79, No. 4, 518-524

[15] M. S. Christian, A. S. Garza and J. E. Slaughter (2011) Work Engagement: A Quantitative Review and Test of its Relations with Task and Contextual Performance. PERSONNEL PSYCHOLOGY, 64, 89-136

[16] M. Onglatco, E. Yuen, C. Leong and G. Lee (1993). Managerial self-efficacy and managerial success in Singapore. International Journal of Management, 10, 14-21.

[17] N. Mat (2008) cross-functional new product development (NPD): characteristics, dynamics and NPD performance. PhD thesis submitted to Universiti Sains Malaysia.

[18] O. Awoyemi (2009). Corporate Governance -Financial Crisis and the Nigerian Leadership Meltdown, MD/CEO of Proshare Nigeria September 28, 2009.

[19] Orr, J. M., Sackett, P. R., \& Mercer, M. (1989). The role of prescribed and nonprescribed behaviors in estimating the dollar value of performance. Journal of Applied Psychology, $74,34-40$

[20] R. A. McCloy, J. P. Campbell, and R. Cudeck (1994) A Confirmatory Test of a Model of Performance Determinants Journal of Applied Psychology . Vol. 79, No. 4,493-505.

[21] S. J. Motowidlo and J, R. Van Scotter (1994) Evidence That Task Performance Should Be Distinguished From Contextual Performance Journal of Applied Psychology. Vol. 79. No. $4.475-480$

[22] S. J. Motowidlo, J. S. Packard and M. R. Manning (1986) Occupational stress: Its causes and consequences for job performance. Journal of Applied Psychology, 71, 618-629.

[23] W. C. Borman and D. H. Brush (1993). More progress toward a taxonomy of managerial performance requirements. Human Performance, 6, 1-21.

[24] W. C. Borman, L. A. White and D. W. Dorsey (1995) Effects of Ratee Task Performance and Interpersonal Factors on Supervisor and Peer Performance Ratings Journal of Applied Psychology, Vol. 80, No. I, 168-177 